\title{
BOTANICAL OILS OF FENUGREEK, PUMPKIN AND SWEET ALMOND: GAS CHROMATOGRAPHY- MASS SPECTROMETRY (GC-Ms) ANALYSIS, ITS EFFECTS ON MULBERRY SILKWORM, BOMBYX Mori L.
}

\author{
Walaa Sallam ${ }^{1}$, F. El-Santeel ${ }^{1}$; EL-Sharkawy, $H^{1}$. and Saad, M. I $^{2}$. \\ 1. Department of Plant Production, Faculty of Technology and Development, \\ Zagazig University, Egypt \\ 2. Plant Protection Research Institute, A.R.C., Dokki, Giza-Egypt. \\ e.mail: adamadham444@gmail.com,hamzash@hotmail.com
}

\section{ABSTRACT:}

The present investigations were carried out during two spring seasons, 2019-2020 in the silkworm laboratory of Sericulture Department of Plant Protection Research Institute, Sharkia Branch to investigate the effect of fenugreek, pumpkin and sweet almond oils on silk production of mulberry silkworm Bombyx mori $L$.

The obtained results cleared that all of these plants oils, fenugreek; pumpkin and sweet almond oils composed of many methylated fatty acids fraction which have many effects of fresh cocoon weight, shell cocoon weight, silk ratio, silk filament weight and size, whereas the fenugreek oil consisted of forty-eight compounds (Hexadecanoic acid, methyl ester, 9-Octadecenoic acid (Z)-, methyl ester, 9,12-Octadecadienoic acid (Z,Z)-, methyl ester and Hexadecanoic acid, methyl ester etc.....), pumpkin consisted of seventy-two ( 9,12Octadecadienoic acid (Z,Z)-, methyl ester, Hexa decanoic acid, methyl ester, Methyl stearate, Dodecanoic acid, methyl ester and Tridecanoic acid, 12-methyl-, methyl ester etc.....) and sweet almond oil consisted of sixteen compounds (Hexadecanoic acid, methyl ester, 9,12Octadecadienoic acid (Z,Z)-, methyl ester, 9-Octadecenoic acid (Z)-, methyl ester, Methyl stearate and Hexanal dimethyl acetal etc....). Fenugreek, pumpkin and sweet almond oils improved cocoon indices and silk filament characters as a profitable supplementary diet for silk worm Bombyx mori L.

Conclusively, the fenugreek, pumpkin gave the highest mean of silk filament length. Fenugreek, sweet almond and pumpkin oils improved cocoon indices and silk filament characters as a profitable supplementary diet for silk worm Bombyx mori L.

keywords: Fenugreek, Sweet almond, pumpkin oils, Mulberry silkworm Larvae, Bombyx Mori L. 


\section{INTRODUCT:}

The silk industry depends on the growth of silkworm that depends on body weight increase and the biochemical components accumulation of food like protein, amino acids and enzymes (Eman and Marwa 2017).

The plants oils could be used for nutrition silkworm to improve silkworm development and silk production, they are making as antimicrobial activity with no side effects on it (Eman and Marwa 2017, Tabassum and Vidyasagar 2013). They have a nutrition profile as a good source of (vitamins E, niacin, riboflavin, etc.), minerals (potassium, phosphorus, magnesium, calcium, iron, zinc, manganese, selenium, copper, etc.), macronutrients (proteins, carbohydrates, fibers, etc.) and fatty acid (saturated, monosaturated and polyunsaturated).

The chemical and nutritional composition have been shown to be significantly decrease the risk of diseases, antioxidation and anti-inflammatory action.

Therefore, the aim of this study to evaluate botanical oils of fenugreek, pumpkin and sweet almond: gas chromatography- mass spectrometry (gc-ms) analysis, its effects on mulberry silkworm, Bombyx mori L.

\section{MATERIALS AND METHODS}

The present investigations were carried out during two spring seasons, 2019 and 2020 in silkworm laboratory of Sericulture Department of Plant Protection Research Institute, Sharkia Branch. The following experiments were carried out:

\section{1- Feeding technique:}

The tested materials were used solely at three concentrations $(1,2$ and $3 \%)$. Three replicates of 30 silkworm larvae for each concentration were fed, throughout 4th \&5th instars on mulberry leaves sprayed on the tested concentrations of each material then left to dry under laboratory conditions. Three replicates were sprayed in distilled water as control, larvae of each replicate were reared on a plastic tray $(100 \times 70 \times 15 \mathrm{~cm})$ under at laboratory conditions $27 \pm 2^{\circ} \mathrm{C}$ and $95 \pm 5 \% \mathrm{RH}$ for the first three instar (1-3), while it was changed for the last two (fourth and fifth instars) to $24 \pm 2{ }^{\circ} \mathrm{C}$ and $75 \pm 5 \% \mathrm{RH}$. All rearing trays, racks and tools, as well as the rearing rooms were sterilized with formalin (5\%) one week before the beginning of the experiment. The tested larvae were fed daily at 8 am, 12 noon, 4 and $8 \mathrm{pm}$. Five full grown larvae/ replicate were weighted, individually then the two silk glands of each larva were dissected out on a filter paper then weighed on a digital balance.

Mature larvae were handly transferred to carton paper (that used wrapping table eggs) for mounting process (Zannoon and Shadia, 1994). The cocoons were harvested 7 days later. Five freshes of the resulted cocoons of each replicate were taken for measuring the cocoon indices (fresh cocoon 
weight, cocoon shell weight and silk ratio), whereas, half of rest cocoons were dried in an oven (oven temperature was raised gradually until it reached $80^{\circ} \mathrm{C}$ for 6 hour) to study filament characters (filament length, filament weight and filament size). Another half of the cocoons were used for the biological studies. After emergence, each couple was impaired in paper saccule for copulation and oviposition.

\section{2- Spraying leaf technique:}

In this trail, the leaves spraying technique was used to evaluate the effect of doses of some concentrations for the tested compounds on the $4^{\text {th }}$ and $5^{\text {th }}$ instars larvae. The sprayed leaves were left to dry and provide to larvae (30 larvae for each concentration) in treatments and control. The biology, physiology and productivity measures were investigated.

\section{3- Measurements:} follows:

The technological parameters were measured in both experiments as

\section{1- Technological parameters:}

\subsubsection{Cocoon indices:}

The following parameters were measured:

A- Fresh cocoon weight $(\mathrm{g})$.

B- Cocoon shell weight $(\mathrm{g})$.

C- Cocoon shell ratio $=\times 100$ (Krishnaswami, 1978).

\subsubsection{Reelable silk filament parameters:}

The weight $(\mathrm{g})$ and length $(\mathrm{m})$ of reeled silk filament were measured and recorded. The size of the reeled filament (denier) was estimated according to (Krishnaswami, 1978) formula:

The size of reeled filament $=\frac{\text { weight of realed filament }(\mathrm{g})}{\text { Length of realed filament }(\mathrm{m})} \times 9000$

Data obtained were statistically analyzed according to Snedecor and Cochran (1982) methods using software COSTAT program.

\subsection{BOTANICAL STUDIES:}

\subsubsection{Methylation:}

The $\mathrm{H} 2 \mathrm{SO} 4$ derivatization method has also been widely used for the analysis of fatty acids in biological samples.H2SO4 -methanol $2 \%(\mathrm{v} / \mathrm{v})$ was added into a vial containing previously weighed $10 \mathrm{mg}$ of fat. The vial was heated at $80 \mathrm{C}$ with occasional shaking. Afterwards, $0.25 \mathrm{~mL}$ of the neutralized aqueous solution (sodium hydroxide $1 \mathrm{M}$ ) was added, and it was smoothly shaken. Before the analysis of the n-hexane phase, the sample was allowed to rest for $5 \mathrm{~min}$ (Masood et al., 2005). The reaction procedure is similar to that 
of other derivatization methods. Because $\mathrm{H} 2 \mathrm{SO} 4$ is a strong oxidizing agent, this method is not recommended for PUFA analysis (Kuksis, 1994; Michal Ski and Łyko, 2010).

\subsubsection{Gas chromatography-mass spectrometry (GC-MS) analysis:}

The chemical composition of plant oils was performed using Trace GC1310-ISQ mass spectrometer (Thermo Scientific, Austin, TX, USA) with a direct capillary column TG-5MS ( $30 \mathrm{~m}$ x $0.25 \mathrm{~mm}$ x $0.25 \mu \mathrm{m}$ film thickness).

The column oven temperature was initially held at $50 \mathrm{C}$ and then increased by $5^{\circ} \mathrm{C} / \mathrm{min}$ to $230^{\circ} \mathrm{C}$ hold for $2 \mathrm{~min}$. increased to the final temperature $290^{\circ} \mathrm{C}$ by $30^{\circ} \mathrm{C} / \mathrm{min}$ and hold for $2 \mathrm{~min}$.

The injector and MS transfer line temperatures were kept at $250,260^{\circ} \mathrm{C}$ respectively; Helium was used as a carrier gas at a constant flow rate of 1 $\mathrm{ml} / \mathrm{min}$. The solvent delay was $3 \mathrm{~min}$ and diluted samples of $1 \mu \mathrm{l}$ were injected automatically using Autosampler AS1300 coupled with GC in the split mode. EI mass spectra were collected at $70 \mathrm{eV}$ ionization voltages over the range of $\mathrm{m} / \mathrm{z} 40-1000$ in full scan mode. The ion source temperature was set at $200{ }^{\circ} \mathrm{C}$.

The components were identified by comparison of their retention times and mass spectra with those of WILEY 09 and NIST 11 mass spectral database.

\section{RESULTS AND DISCUSSION:}

Part 1: Effect of some plant oils on the technology, and silk production of Bombyx mori L.:

1. Cocoon indices:

\subsection{Fresh cocoon weight (g):}

\subsubsection{Fresh cocoon weight $4^{\text {th }}(\mathrm{g})$ :}

Data presented in (Table1), cleared that the heaviest weight of fresh cocoon was gained $(1.44 \mathrm{~g})$ from the larvae fed on mulberry leaves enriched with fenugreek oil $(1 \%)$, followed by $(2 \%)$ which recorded $(1.43 \mathrm{~g})$ then $(1.35 \mathrm{~g})$ for $(3 \%)$ fenugreek oil compared with control $(1.42 \mathrm{~g})$ and $(0.59 \mathrm{~g})$ for tween. Generally, data analysis revealed that there were high significant between concentrations and also high significant between treatments.

\subsubsection{Fresh cocoon weight $5^{\text {th }}(\mathrm{g})$ :}

Data presented in (Table2), cleared that the heaviest weight of fresh cocoon was gained $(1.45 \mathrm{~g})$ from the larvae fed on mulberry leaves enriched 


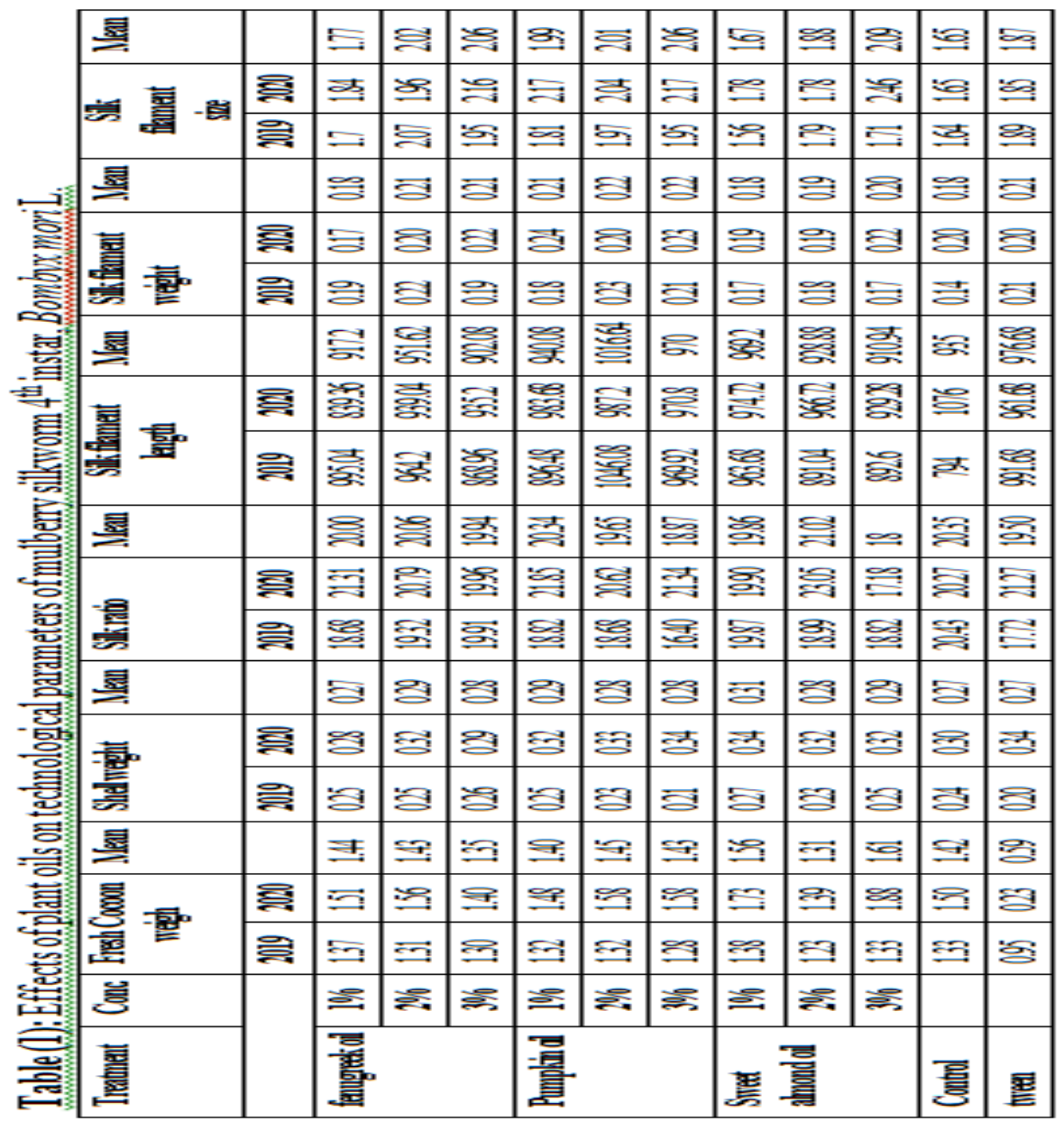


WALAA SALLAM et al.

\begin{tabular}{|c|c|c|c|c|c|c|c|c|c|c|c|c|}
\hline 表 & 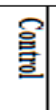 & & & 䇺 & & & 凅 & & & $=$ & & 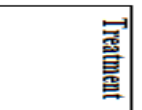 \\
\hline & & $\tilde{3}$ & : & 5 & $=$ & 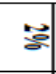 & 5 & 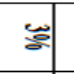 & : & 5 & & है \\
\hline 氡 & 意 & $\overline{5}$ & $\overline{5}$ & 实 & 토 & 두 & 호 & 항 & $=$ & E & : & 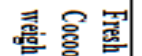 \\
\hline 罟 & : & 㤐 & 荧 & 案 & 宮 & 敀 & 官 & 늡 & 家 & 宫 & 눙 & \\
\hline :5 & :3 & 눈 & : & $E$ & E & 5 & : & 占 & 占 & 붕 & & 量 \\
\hline 영 & 원 & 옳 & 롱 & 홍 & 옳 & 원 & : & 인 & 인 & 른 & : & 管 \\
\hline 용 & 웛 & 웝 & 잋 & 옳 & 용 & 영 & 욣 & 잃 & 웠 & 웛 & 눙 & 苞 \\
\hline 흥 & 른 & 웅 & 응 & 워 & 융 & 잃 & 앙 & 응 & 영 & 영 & & 量 \\
\hline : & 䍠 & : ్ㅜㅇ & 늡 & 吢 & 悹 & 㐱 & 융 & 寀 & 蓖 & 웠 & 总 & 第 \\
\hline 苦 & 논 & 营 & 읍 & : & 苦 & 潈 & 总 & : & : & : & 웅 & \\
\hline 훙 & 영 & 병 & 쿤 & : : & 영 & : & 量 & 홍 & : & : & & 量 \\
\hline 总 & $\vec{p}$ & 怨 & 絯 & 恶 & 惫 & 㝘 & 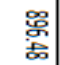 & 愛 & 怼 & 曽 & 븡 & 善笣 \\
\hline 兽 & 塄| & 氮 & 总 & : & 嘉 & 㖕 & 密 & 兽 & 悹 & 旁 & 붕 & \\
\hline 煦 & : & : & 연 & : & : & 옹 & : & 은 & : & 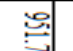 & & 最 \\
\hline 원 & 얃 & 은 & 잏 & 은 & 원 & 웠 & 잃 & 응 & 켠 & 읍 & 氨 & 善第 \\
\hline 롱 & 엃 & 옹 & : & : & 워 & 엉 & 본 & 론 & : & 형 & 웅 & 暨 \\
\hline 콩 & 형 & 으 & 워 & 워 & 워 & 논 & 콩 & 원 & 옹 & 형 & & 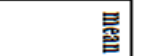 \\
\hline 占 & 蒙 & $\Xi$ & $\overrightarrow{0}$ & 容 & 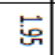 & 宓 & 宮 & 항 & $\tilde{\xi}$ & $\Xi$ & : & 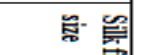 \\
\hline ్ㅜㅇ & 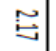 & $\cong$ & : & : & $\tilde{g}$ & $\tilde{\tilde{x}}$ & 종 & $\Xi$ & 吣 & 富 & : & 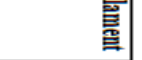 \\
\hline$=$ & 희 & 호 & 옹 & 희 & : & 곃 & 氞 & : & 웧 & : & & \\
\hline
\end{tabular}


with fenugreek oil (3\%), followed by fenugreek (2\%) which recorded $(1.43 \mathrm{~g})$ then $(1.42 \mathrm{~g})$ for pumpkin oil (3\%) compared with control and tween $(1.02 \mathrm{~g})$. Data analysis showed that there was high significance between treatments and concentrations.

The results agree with Morssy, Ghada (2012) indicated that Sesame and Nigella sativa oils at $0.5 \%$ concentration when used two times kept the larvae of Bombyx mori healthy by decreasing mortality rate. Sesame oil and Olive oil at $1 \%$ and Nigila sativa oil at $0.5 \%$ gave the best results on cocoons indices and silk filament characters (length, weight and size).

\subsection{Cocoon shell weight (g):}

\subsubsection{Cocoon shell weight $4^{\text {th }}(\mathrm{g})$ :}

As shown in (Table1), the heaviest cocoon shell weight was recorded for the cocoons spun by B. mori larvae fed during their $4^{\text {th }}$ instar on mulberry leaves fortified with sweet almond oil ( $1 \%$.), recording $(0.31 \mathrm{~g})$, compared to $(0.27 \mathrm{~g})$ for the control and tween, in the first season. Generally, sweet almond and fenugreek oil treatments proved to be the most potent, followed, in descending order, by pumpkin oil treatment. However, all the tested oils improved these parameters over the control. Obtained results in (Table1) indicated that the tested oils induced significant increases in the cocoon shell weight especially with sweet almond oil $1 \%$ that recorded $(0.31 \mathrm{~g})$. Data analysis showed that there were high significant between concentrations and treatments. That results agree with Zeid et al. (2008) observed a remarkable activity against gram-positive bacteria by using oil of Cyperus rotundus. The study of the biological activities of this oil is very important because of needing to be determined whether there is any correlation between the biological activities and one or more of the chemical compounds purified from C. rotundus oil.

\subsubsection{Cocoon shell weight $5^{\text {th }}(\mathrm{g})$ :}

As shown in (Table 2), the heaviest cocoon shell weight was recorded for the cocoons spun by $B$. mori larvae fed during their $5^{\text {th }}$ instar on mulberry leaves fortified with fenugreek oil $(2 \%)$ and pumpkin oil $(3 \%)$ recording $(0.30 \mathrm{~g})$, compared to $(0.23 \mathrm{~g})$ for the control and $(0.20 \mathrm{~g})$ for tween. Data analysis showed that there were high significant between concentrations and treatments for both seasons.

Rehab H. Taha et al. (2017) revealed that, B. bifidumand, S. cerevisiae improved most tested parameters comparing with control. The effect of probiotics may be dependent on the tested B. mori hybrid. Renditta that stands for the quantity of cocoons required for producing a kilogram of raw silk was significantly improved in all supplemented groups either for B. bifidumor, $S$. 
cerevisiae. The lowest cocoon kilograms required to produced one kilo of raw silk was $(5.97 \pm 1.85)$ recorded for hybrid 2 treated with B. bifidum. There is a pronounced increase in the activity of protease, amylase and invertase in probiotic treated worms than control.

\subsection{Silk content ratio:}

\subsubsection{Silk content ratio $4^{\text {th }}$ :}

Data in (Table 1) cleared that the highest silk content ratio were $(21.02 \%)$ and $(20.34 \%)$ recorded for the cocoon spun by B. mori larvae fed in their $4^{\text {th }}$ instar on mulberry leaves enriched with sweet almond oil $(2 \%)$ and pumpkin oil (1\%) respectively, compared with (20.35) for control and (19.50g) for tween. Data analysis cleared that there was no significance between concentrations and significance between treatments in the first season, and also there were no significant between treatments in the second season.

Also, Youssef and Mona (2014): evaluated the effect of the essential oils (EOs) of fennel (Foeniculum vulgare) and caraway (Carum carvi), against larval instars of silkworm by using a leaf-dipping bioassay. The tested EOs had no adverse effects on the growth rate and silk production of the larvaeexcept at the higher concentrations at which these were slightly decreased in the later development stages. This experiment is one of the first attempts to understand the key role of EOs in regulating insect growth and development although further studies at physiological levels are required. In conclusion, these findings could contribute to the IPM of insect pests on mulberry without adversely affecting the silkworm-breeding industry.

\subsubsection{Silk content ratio $5^{\text {th }}$ :}

Data in (Table 2) cleared that the highest silk content ratio were (22.61) and (22.30) recorded for the cocoon spun by B. mori larvae fed in their $5^{\text {th }}$ instar on mulberry leaves enriched with fenugreek (1\%) and sweet almond oil (3\%) respectively, compared with (23.80) for control and (20.90\%) for tween. Data analysis cleared that there was high significance between concentrations and treatments in both seasons.

Changing in the concentrations of fenugreek, pumpkin and sweet almond oils make change in rate of growth by increasing and the cocoon weigh, all treatments were the important to make the value of cocoon characters. The results are in agreement with Rateb and Abdel-Rahman (2015) cleared that initial, final average and range of 5th instar weight, growth index, silk glands weight, ratio between silk glands and larval weight, pupal weight, fresh and cocoon, shell weight and cocoon shell ratio \% was calculated. Using of aqueous extract of Rosemary on imported silkworms leads to an increase in cocoon shell ratio \%. Concerning local hybrid this increment was detected in 
C. durant, Moringa, and Garlic treatments. All tested aqueous extracts increased cocoon shell ratio \% in local hybrid. Generally, in im-ported hybrid, the only increment in cocoon shell ratio \% was in aqueous extracts of Rosemary treatment. However, in local hybrid this increment was found in alcoholic extracts of Moringa, Garlic, $C$. durant. This reflects more response of local hybrid as compared with imported one. Also, response to aqueous extracts was more than the alcoholic extracts. Thus, using of local hybrid of silkworm and treatment of mulberry leaves with aqueous extract is considered be available easier and cheaper for feeding of mulberry silkworms, in Egypt.

\section{Reeled silk filament parameters:}

Reeled silk filament characters, length (m), weight (g) and size (denier) were measured in the cocoons resulted from silkworm larvae fed during 4th $\& 5$ th instars on the leaves of mulberry treated with tested oils, (Tables, $1 \& 2$ ).

\subsection{Silk filament length $(m)$ :}

\subsubsection{Silk filament length $4^{\text {th }}(\mathrm{m})$ :}

As shown in (Table 1), the highest mean treatment length of reeled silk filament of cocoon spun by B. mori larvae fed during $4^{\text {th }}$ instar on treated mulberry leaves with pumpkin oil 2\% (1016.64 m), followed by pumpkin oil 3\% recording $(970.8 \mathrm{~m})$, while sweet almond oil $1 \%$ recorded $(969.2 \mathrm{~m})$. On the other hand, control cocoon gave $(935 \mathrm{~m})$. In addition, all the tested additives caused significant prolongation in silk filament length as compared of the control. Khalil et al. (2006) studied the influence of some supplementary nutrition's on the production of silk worms and increasing its productivity. Addition of various concentrations of anise extract gave the best values in terms length, width, weight of the cocoons and floss, and pupal weight.

\subsubsection{Silk filament length $5^{\text {th }}(\mathrm{m})$ :}

As shown in (Table 2), the highest mean treatment length of reeled silk filament of cocoon spun by B. mori larvae fed during $5^{\text {th }}$ instar on treated mulberry leaves with sweet almond oil $1 \%(986.74 \mathrm{~m})$, followed by sweet almond oil 3\% recording $(956 \mathrm{~m})$, while pumpkin oil 3\% recorded $(955.36 \mathrm{~m})$. On the other hand, control cocoon gave $876.75 \mathrm{~m}$. In addition, all the tested additives caused significant prolongation in silk filament length as compared of the control.

Also, Mohamed, Magda (2002) studied the influence of some vegetable oils (black cumin oil, sunflower oil and linen seed oil) with different concentrations on the mulberry silkworm, Bombyx mori productivity. The author stated that the studied vegetable oils induced higher mean of fifth larval instar weight at the lower concentration $(0.05 \%)$ than those recorded under the higher concentration $(0.5 \%)$. The highest mean $(2.587 \mathrm{~g})$ was obtained from the 
treatment of 0.05 linen oil, while 0.5 black cumin oil treatment gave the lowest one $(2.383 \mathrm{~g})$, followed by the control treatment $(1.846 \mathrm{~g})$. The heaviest mean weights of silk gland $(0.578 \mathrm{~g})$ and cocoon shell $(0.236 \mathrm{~g})$ were recorded at $0.05 \%$ sunflower oil treatment. She added that the lower concentration of linen oil gave the highest mean weight of cocoon and pupa as well as the mean number of deposited eggs /female, showing values of $1.260 \mathrm{~g}, 1.037 \mathrm{~g}$ and 568.4 eggs, respectively.

\subsection{Silk filament weight (g):}

\subsubsection{Silk filament weight $4^{\text {th }}(\mathrm{g})$ :}

As shown in (Table 1) the highest mean treatment reeled silk filament weight $(0.22 \mathrm{~g})$ was recorded for the cocoons spun by B. mori larvae fed on pumpkin oil ( $2 \& 3 \%$ ), followed by that of the larvae offered enriched mulberry leaves with fenugreek $(2 \& 3 \%)$ and pumpkin $1 \%$ recording $(0.21 \mathrm{~g})$ Meanwhile, control silk filament weighed was $(0.18 \mathrm{~g})$. Data analysis indicated that there were high significant between concentration and treatment in both seasons.

\subsubsection{Silk filament weight $5^{\text {th }}(\mathrm{g})$ :}

As shown in (Table 2) the highest mean treatment reeled silk filament weight $(0.26 \mathrm{~g})$ was recorded for the cocoons spun by B. mori larvae fed on fenugreek oil (2\%), followed by that of the larvae offered enriched mulberry leaves with pumpkin (3\%) recording $(0.24 \mathrm{~g})$ Meanwhile, control silk filament weighed was $(0.20 \mathrm{~g})$. Data analysis indicated that there were high significant between concentration and treatment in both seasons.

\subsection{Silk filament size (denier):}

\subsubsection{Silk filament size $4^{\text {th }}$ (denier):}

As shown in (Table 1) the highest mean treatment reeled silk filament size (2.09 denier) was recorded for the cocoons spun by B. mori larvae fed on sweet almond oil (3\%), followed by that of the larvae offered enriched mulberry leaves with fenugreek and pumpkin $(3 \& 3 \%)$ recording $(2.06 \mathrm{~g})$ Meanwhile, control silk filament weighed was $(1.65 \mathrm{~g})$. Data analysis indicated that there were high significant between concentration and treatment in both seasons.

\subsubsection{Silk filament size $5^{\text {th }}$ (denier):}

As shown in (Table 2) the highest mean treatment reeled silk filament size (2.70 denier) was recorded for the cocoons spun by B. mori larvae fed on fenugreek oil $(2 \%)$, followed by that of the larvae offered enriched mulberry leaves with fenugreek (3\%) recording (2.60g) Meanwhile, control silk filament weighed was $(1.91 \mathrm{~g})$. Data analysis indicated that there were high significant between concentration and treatment in both seasons. 
Also, Waktole and Bhaskar (2015) showed that feeding of fortified leaves with the plant extracts led to better larval growth and development which ultimately reflected in the economic traits of $\mathrm{PM} \times \mathrm{CSR} 2$ silkworm hybrid. Fifth instar 5th day larval weight (26.25 and $27.52 \mathrm{~g} / 10$ ), mature larval weight (28.63 and $30.13 \mathrm{~g} / 10$ ), ERR (98.33 and 100.00\%), cocoon weight (18.06 and $18.79 \mathrm{~g} / 10$ ), shell weight (3.68 and $3.72 \mathrm{~g} / 10$ ), pupal weight (14.30 and $15.23 \mathrm{~g} / 10$ ), shell ratio (20.38 and 19.80\%), filament length (901.03 and $910.95 \mathrm{~m}$ ) and silk productivity (4.04 and $4.097 \mathrm{cg}$ per day) in two rearing were found significantly maximum for $P$. coryleifolia fortified leaves fed worms followed by $P$. niruri besides reducing larval duration and cocoon filament denier compared to other treatments. Thus, fortification of mulberry leaves with $P$. coryleifolia and $P$. niruri leaf extracts had favorably influenced $\mathrm{PM} \times \mathrm{CSR} 2$ larval growth leading to significantly better economic traits. There is a need to identify the active principle(s), standardize and formulate the botanicals and develop better administration techniques for commercial silkworm rearing.

\section{Part 2: Total ionic chromatography of botanical oils (GCMAs): \\ 1- Total ionic chromatography of fenugreek oil:}

The analytical data obtained from GLC spectrum of methylated fatty acids fraction was shown in the Figs (1) and presented in the Table (3), these data illustrated that, there are forty-eight compounds of Trigonella oil.

Five compounds were detected, namely Hexadecenoic acid, methyl ester, 9-Octadecenoic acid (Z)-, methyl ester, 9,12-Octadecadienoic acid (Z,Z), methyl ester, Methyl stearate and Hexadecenoic acid, methyl ester.

Hexadecenoic acid, methyl ester is the major compound (31.51\%) at retention time (29.07: 29.22) while Methyl stearate (12.13\%) at retention time (33.04) is the minor one of fenugreek oil, respectively.

On the other hand, there are eleven compound; Methyl 18methylnonadecanoate is the major compound (3.35\%) at retention time (36.31) comparable with the other ones followed by 9 -Hexadecenoic acid, methyl ester, (Z)- (2.12\%) and Hexanal dimethyl acetal (1.09\%) and cis-Methyl 11eicosenoate $(1.46 \%)$ while 9,12 -Octadecadienoyl chloride, $(\mathrm{Z}, \mathrm{Z})$ - is found in trace percent $(1.03 \%)$ in fenugreek. 
Table (3): Total Ionic) for plant oils (fenugreek, pumpkin and sweet almond oil). Chromatography (GCMAs

\begin{tabular}{|c|c|c|c|c|}
\hline Treatment & Commn name & $\begin{array}{l}\text { Empirical } \\
\text { formula }\end{array}$ & Retention time & $\begin{array}{l}\text { Relative } \\
\text { percentage }\end{array}$ \\
\hline \multirow[t]{5}{*}{ Fenugreek oil } & $\begin{array}{l}\text { Hexadecanoic acid, } \\
\text { methyl ester }\end{array}$ & $\mathrm{C} 17 \mathrm{H} 34 \mathrm{O} 2$ & 29.07 & 18.78 \\
\hline & $\begin{array}{l}\text { 9-Octadecenoic acid (Z)- } \\
\text {, methyl } \\
\text { ester }\end{array}$ & $\mathrm{C} 19 \mathrm{H} 36 \mathrm{O} 2$ & 32.84 & 13.22 \\
\hline & $\begin{array}{l}\text { 9,12-Octadecadienoic } \\
\text { acid (Z,Z)-, } \\
\text { methyl ester }\end{array}$ & $\mathrm{C} 19 \mathrm{H} 34 \mathrm{O} 2$ & 32.22 & 12.99 \\
\hline & Methyl stearate & $\mathrm{C} 19 \mathrm{H} 38 \mathrm{O} 2$ & 33.04 & 12.13 \\
\hline & $\begin{array}{l}\text { Hexadecanoic acid, } \\
\text { methyl ester }\end{array}$ & $\mathrm{C} 17 \mathrm{H} 34 \mathrm{O} 2$ & 29.14 & 8.31 \\
\hline \multirow[t]{5}{*}{ Pumpkin oil } & $\begin{array}{l}\text { 9,12-Octadecadienoic } \\
\text { acid (Z,Z)-, methyl } \\
\text { ester }\end{array}$ & $\mathrm{C} 19 \mathrm{H} 34 \mathrm{O} 2$ & 32.32 & 37.07 \\
\hline & $\begin{array}{l}\text { Hexa decanoic acid, } \\
\text { methyl ester }\end{array}$ & $\mathrm{C} 17 \mathrm{H} 34 \mathrm{O} 2$ & 29.14 & 17.94 \\
\hline & Methyl stearate & $\mathrm{C} 19 \mathrm{H} 38 \mathrm{O} 2$ & 32.93 & 7.47 \\
\hline & $\begin{array}{l}\text { Dodecanoic acid, methyl } \\
\text { ester }\end{array}$ & $\mathrm{C} 13 \mathrm{H} 26 \mathrm{O} 2$ & 20.18 & 6.15 \\
\hline & $\begin{array}{l}\text { Tridecanoic acid, 12- } \\
\text { methyl-, } \\
\text { methyl ester }\end{array}$ & $\mathrm{C} 15 \mathrm{H} 30 \mathrm{O} 2$ & 24.77 & 4.33 \\
\hline \multirow[t]{5}{*}{ Sweet almond oil } & $\begin{array}{l}\text { Hexadecanoic acid, } \\
\text { methyl ester }\end{array}$ & $\mathrm{C} 17 \mathrm{H} 34 \mathrm{O} 2$ & 28.98 & 19.67 \\
\hline & $\begin{array}{l}\text { 9,12-Octadecadienoic } \\
\text { acid (Z,Z)-, methyl ester }\end{array}$ & C19H34O2 & 32.22 & 22.80 \\
\hline & $\begin{array}{l}\text { 9-Octadecenoic acid (Z)- } \\
\text {, methyl ester }\end{array}$ & $\mathrm{C} 19 \mathrm{H} 36 \mathrm{O} 2$ & 32.33 & 14.29 \\
\hline & Methyl stearate & $\mathrm{C} 19 \mathrm{H} 38 \mathrm{O} 2$ & 32.77 & 6.49 \\
\hline & Hexanal dimethyl acetal & $\mathrm{C} 8 \mathrm{H} 18 \mathrm{O} 2$ & 5.86 & 4.43 \\
\hline
\end{tabular}

\section{2- Total ionic chromatography of pumpkin oil:}

The analytical data obtained from GLC spectrum of methylated fatty acids fraction was shown in the Figs (2) and presented in the Table (3), these data illustrated that, there are seventy-two compounds of pumpkin oil.

Five compounds were detected, namely 9,12-Octadecadienoic acid (Z,Z), methyl ester, Hexa decanoic acid, methyl ester, Methyl stearate, Dodecanoic acid, methyl ester and Tridecanoic acid, 12-methyl-methyl ester.

9,12-Octadecadienoic acid (Z,Z)-,methyl ester is the major compound (37.07 \%) at retention time (32.32) while Tridecanoic acid, 12-methyl-, methyl ester $(4.33 \%)$ at retention time $(24.77)$ is the minor one of pumpkin oil, respectively. 


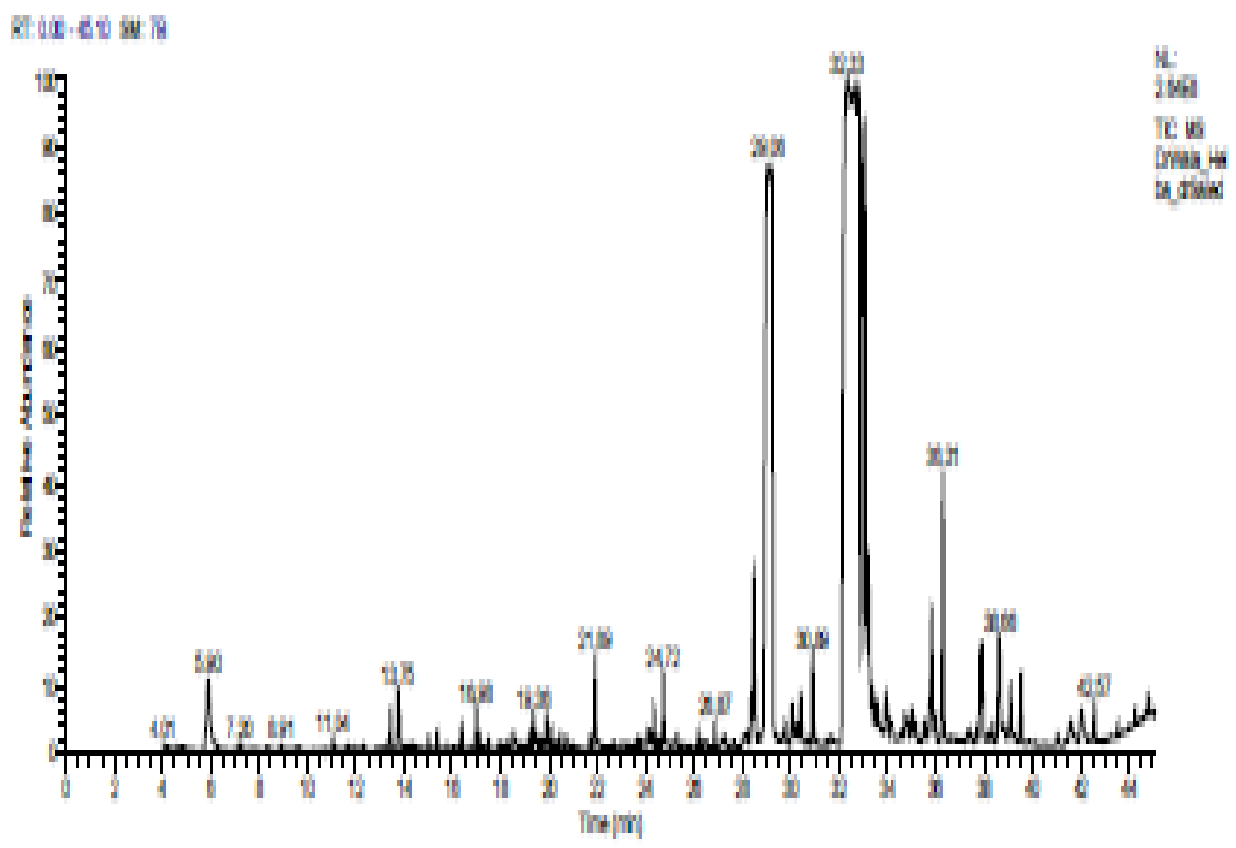

Fig. (1): Total ionic chromatography of fenugreek oil.

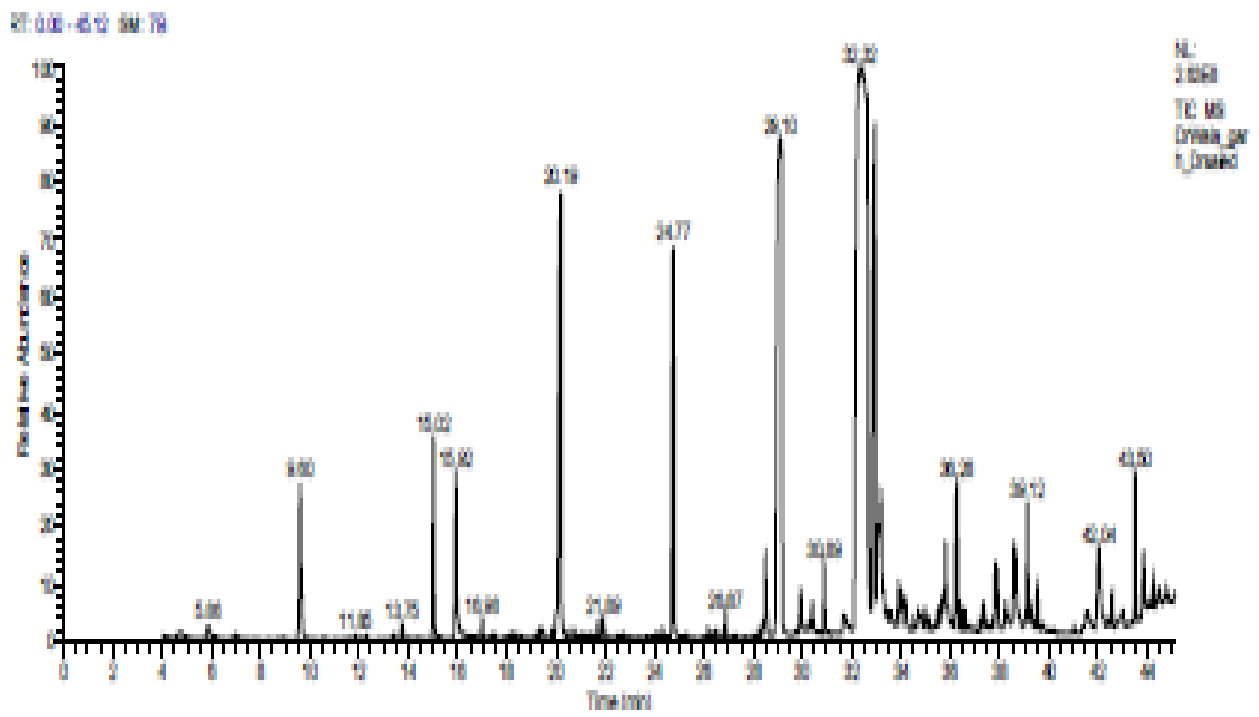

Fig. (2): Total ionic chromatography of pumpkin oil. 
On the other hand, there are sixty-seven compounds; Eicosanoic acid, methyl ester is the major compound $(2.05 \%)$ at retention, time (36.28) comparable with the other ones followed by Octanoic acid, methyl ester (1.81 $\%)$ and Decanoic acid, methyl ester (1.74 \%) and Phenol, 2-methoxy-3-(2propenyl)- $(1.60 \%)$ while 13 -Docosenoic acid, methyl ester, $(Z)$-is found in trace percent $(1.09 \%)$ in pumpkin.

\section{3- Total ionic chromatography of sweet almond oil:}

Analytical data obtained from GLC spectrum of methylated fatty acids fraction was shown in the Figs (3) and presented in the Table (3), these data illustrated that, there are sixteen compounds of sweet almond oil. compounds were detected, namely Hexadecanoic acid, methyl ester, 9,12-Octadecadienoic acid (Z,Z)-, methyl ester, 9-Octadecenoic acid (Z)- methyl ester, Methyl stearate, Hexanal dimethyl acetal and Heptane, 1,1-dimethoxy.

Hexadecanoic acid, methyl ester is the major compound $(19.67 \%)$ at retention time (28.98) while Heptane, 1,1-dimethoxy (3.34\%) at retention time (16.98) is the minor one of sweet almond oil, respectively.

On the other hand, there are ten compounds; Linoelaidic acid is the major compound $(3.22 \%)$ at retention, time (33.04) comparable with the other ones followed by 8,8-dimethoxy-2-octen-1-al (2.89\%) and Oleic Acid (2.78 $\%$ ) while 2-Octanol, 8,8-dimethoxy, $(Z)$ - is found in trace percent $(1.19 \%)$ in sweet almond oil.

In Harmony, Arnoldo et al. (2018) showed that sweet almond oil showed better performance under extreme pressure conditions and a greater weld point than mineral oils. Finally, an FTIR spectroscopic analysis allowed determining that under the conditions of the current assays almond oil does not oxidize. Also, Sowmya and Nishter (2017) showed that free radicals are generated by various biochemical pathways in the living system, causing severe oxidative damage to the biomolecules leading to adverse disease conditions. Hence, there is an increasing interest in antioxidant studies for preventing the effects of these free radicals. Herein, we propose a novel electro-spun scaffold with antioxidant properties that can be used as wound healing material. Fenugreek, a natural antioxidant incorporated silk fibroin nanofiber, was prepared in four different ratios by the co-electrospinning method. The biocompatibility of the nanofibers and its antioxidant activity were evaluated through 3-(4, 5-dimethylthiazol-2-yl)-diphenyltetrazolium bromide (MTT) assay and 1,1-diphenyl-2-picrylhydrazyl (DPPH) scavenging assay, respectively. The experimental observations indicate that the incorporation of fenugreek increases the thermal and mechanical properties of silk fibroin nanofibers. DPPH assay proves that the antioxidant property is 


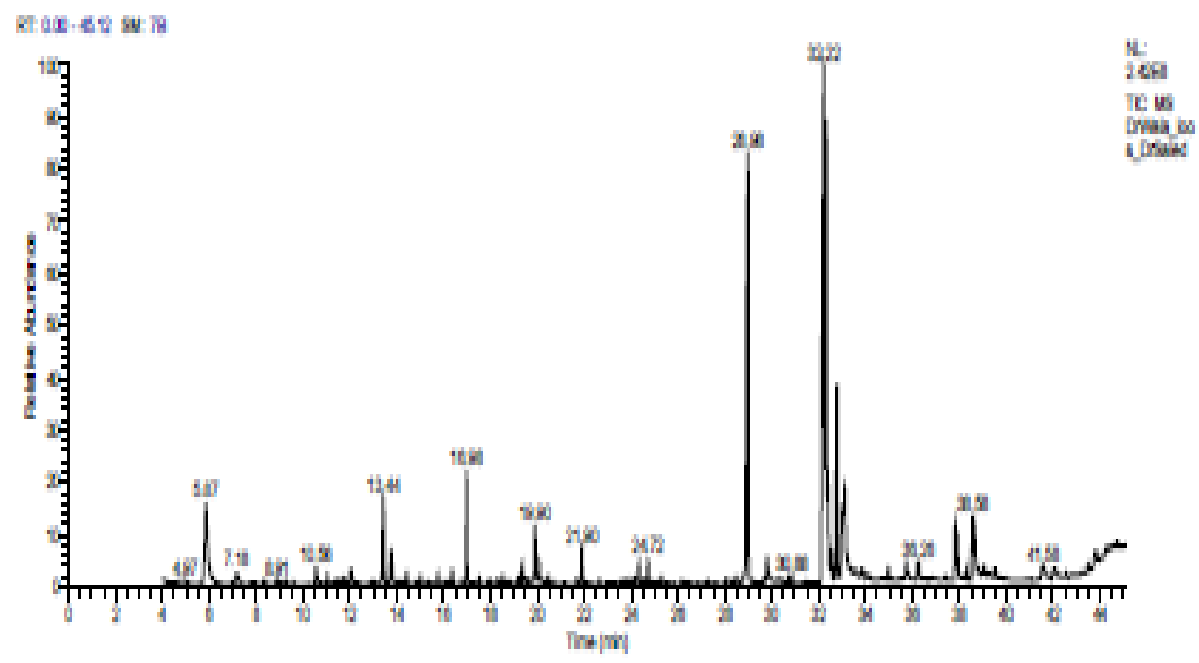

Fig. (3): Total ionic chromatography of sweet almond oil.

enhanced with increasing concentration of fenugreek in nanofiber mats, and the Swiss albino 3T6 fibroblasts show better proliferation on the nanofibrous scaffolds. Further, the wound healing efficiency of fenugreek incorporated silk fibroin nanofibrous scaffolds was evaluated using full thickness excisional wounds in rat model. Wound healing was accelerated in silk fibroin-fenugreek nanofibers treated wounds with complete re-epithelialization and enhanced collagen deposition. The present study validates the use of fenugreek incorporated silk fibroin nanofiber mats as antioxidant scaffolds in wound healing.

Conclusively, the result cleared that the isolated components of fenugreek oil are forty-eight compounds, the isolated components of pumpkin oil are seventy-two and the isolated components of sweet almond oil are sixteen compounds that are given increasing on fresh cocoon weight, shell cocoon weight and silk ratio and silk filament length. Fenugreek oil, sweet almond oil and pumpkin oil improved cocoon indices and silk filament characters.

\section{REFERENCES:}

Arnoldo E. D. T., William A. A. C. and Rafael G. G. C. (2018): Evaluation of the lubricating power of sweet almond oil without additives. DelgadoTobón et al. / Revista DYNA, 85 (205): 179-183. 
Eman M. H. and Marwa N. (2017): Effect of Some Essential Oils and Natural Botanical Extracts on Food Consumption and Some Physiological Aspects of Mulberry Silkworm, Bombyx mori L. Egypt. Acad. J. Biolog. Sci., 8 (1): 71 -80.

Khalil, M.; Tammam, A. A. and Okasha, E. (2006): "Influence of nutrient supplements on silkworm production of Bombyx mori L.". Tishreen University. J. of Scientific Biol. Sci. Series, (22) No (1).

Krishnaswami, S. (1978): New technology of silkworm rearing central Sericulture Researches and Training, Inst., Mysore Bull., 2:1-10.

Kuksis, A. (1994): Advanced as in lipids methodology- two: edited by ww christie, the scoltish crop research institute, innergowrie Dundee DD 22 5DA. Scotland published by the oily press Dundee p. 1993.

Michal Ski, R. Lyko, A. (2010): determination of bromate in water sample using post column derivatization method with triiodide J. Environ. Sci. Health part A 45 (10), 1275-1280.

Mohamed, Magda. A. (2002): "Influence of some vegetable oils on the mulberry silkworm, Bombyx mori L. productivity". 2nd International Conference, Plant Protection Research Institute, Cairo, Egypt, 21-24 December, Vol. 1 page 216-221.

Morssy, Ghada, M. (2012): "Biological, physiological and technological studies on silkworm, Bombyx mori L." Ph.D Thesis, Fac. of Agric. Benha Univ., Egypt.

Rateb, S.H. and Abdel-Rahman Y. A. (2015): Effects of some Extracts on Growth Characters of Mulberry Silkworm B. mori L. Assiut J. Agric. Sci., 46 (5): 58-71.

Rehab H. Taha; Soliman S. A. and Hamzah M. K. (2017): MicroOrganisms Supplementation to Mulberry Silkworm, B. mori L. Egypt. Acad. J. Biolog. Sci., 10 (2): 57-64.

Sndecor, G. W. and Cochran, W. G. (1982): Statistical Methods. Iowa state Univ. Press, Amer. Iowa.

Sowmya S. and Nishter N. F. (2017): Fenugreek Incorporated Silk Fibroin Nanofibers-A Potential Antioxidant Scaffold for Enhanced Wound Healing. ACS Applied Materials, 9 (7): 5916-5926.

Tabassum, N. and Vidyasagar, G.M. (2013): Antifungal investigations on plant essential oils, Review. Int. J. Pharm. Sci., 5(2): 19-28.

Waktole S. G. and Bhaskar R. N. (2015): Fortification of Mulberry Leaves with Medicinal Botanical Plant Extracts Effect on Silkworm, B. mori L. (PM $\times$ CSR2) (Lepidoptera: Bombycidae) Larval Growth and Cocoon Traits. Journal of Biological Sciences, 15: 199-206. 
Youssef Dewer and Mona M. Mahmoud (2014): Effectiveness and safety of some essential oils of aromatic plants on the growth and silk production of the silkworm B. mori L. J. of Entomology and Zoology Studies; 2 (2): 81-86.

Zannoon, A. A. and Shadia M. O. (1994): "Efficiency of certain natural materials as mountages for mulberry silkworm, Bombyx mori L.". Egypt. J. Appl. Sci., 9 (8): 691-696.

Zeid, A. N.; Majid, S. J.; Raghidah, I. W. and Huda, A. H. (2008): "Extraction, Identification and Antibacterial activity of Cyperus oil from Iraqi C. rotundus". Eng. \& Technol., Vol. 26, No.10.

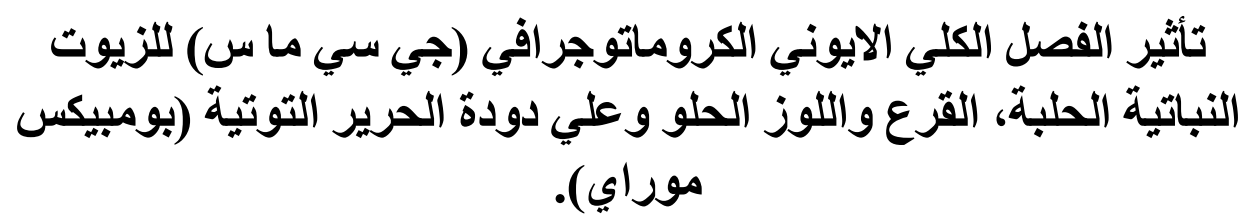

$$
\begin{aligned}
& \text { ولاء سلام } 1 \text { ، فتحى السنطيل1 ، حمزة محمد الثرقاوي 1, محمود سعد ابراهيم } 2
\end{aligned}
$$

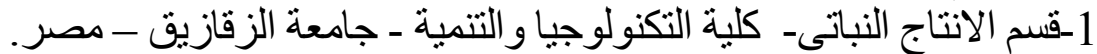

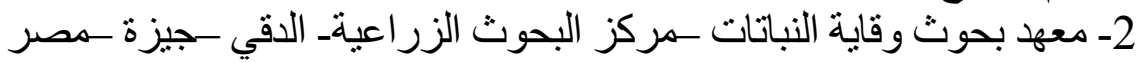

أجريت الدر اسة خلال فصل موسمي ربيع

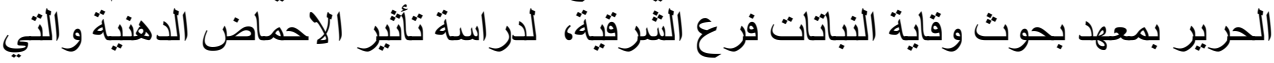

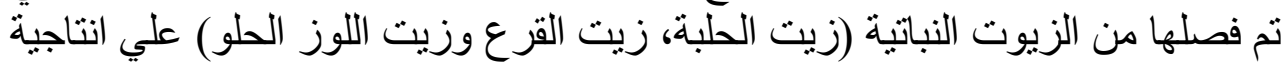
الحرير لدودة الحرير التوتية.

و اثشارت النتائج الي ان زيت الحلبة يتكون من 48 مركبة مركب من الاحماض الدهنية من أهمهم هكسادونك اسيد مثيل استر،9 اوكتادونك اسيد زيد مثيل استر، 9 و و 12

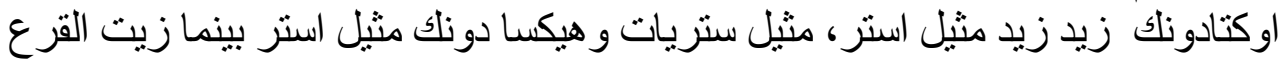

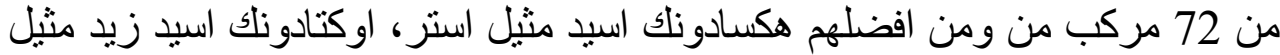

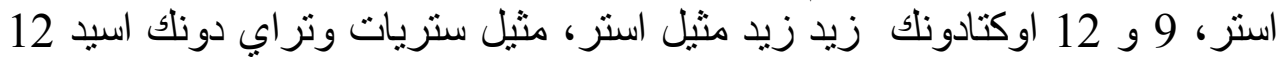
مثيل استر بينمازيت اللوز الحلو من 16 مركب وهي وهم هكسادونك اسبد مثنيل استر ، 12 اوكتادونك زيد زيد مثيل استر، 9 اوكتادونلك اسيد زيد مثيل استر، ميثيل ستريات

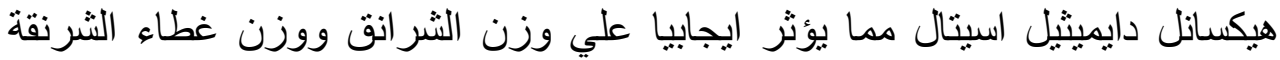
ونسبة الحرير فى قثرة الثرنقة. 
زيت الحلبة وزيت القرع وايضا زيت اللوز الحلو كاضافات غذائية أدت الي تحسين صفات الثرانق والخيط الحريري كنظام غذائي فعال ليرقات ديدان الحرئ الحرير التونية

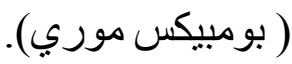

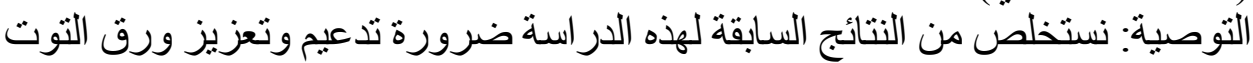

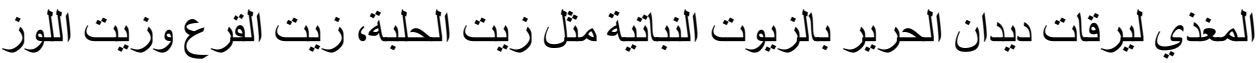
الحلو لانها غنية بالعناصر الهامة لتنشيط وتكوين البروتين المكون الاساسي للخيط

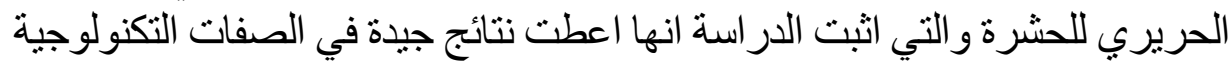

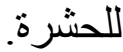

